\title{
QUALITY OF LIFE IMPROVEMENT IN KAIZEN ASPECT
}

doi: 10.2478/cqpi-2019-0071

Date of submission of the article to the Editor: 06/04/2019

Date of acceptance of the article by the Editor: 15/05/2019

\author{
Joanna Rosak-Szyrocka1 - orcid id: 0000-0002-5548-6787 \\ 1 Department of Production Engineering and Safety, Czestochowa University of Technology, \\ Poland, joanna.rosak-szyrocka@wz.pcz.pl
}

\begin{abstract}
The aim of the research is to analyze the quality of life improvement (Kaizen) in the running aspect in Poland. Until now, issues related to the running analysis of the quality life in terms were not the subject of broader, comprehensive scientific considerations. The research was taken in 2019 year and covered a group of 396 runners. The respondents are women posing 67,9\% and men posing $32,1 \%$ residing in different areas of Poland. The research was based on a questionnaire (CAWI - Computer Assisted Web Interview). Although for most respondents the result is not the most important, they try to improve their running attitude and time. Runners use different ways to be motivated to work on themselves. An example of motivators can be a medal, obtained at the finish line or sharing success with participation in competition on social networks (Facebook).
\end{abstract}

Keywords: Kaizen, quality of life, running, improvement

\section{WHAT IS KAIZEN? - LITERATURE REVIEW}

Imai defined Kaizen as: "a means of continuing improvement in personal life, home life, social life, and working life. At the workplace, Kaizen means continuing improvement involving everyone - managers and workers alike" (Manuel et al., 2013). Kaizen's consignment states that no day should pass without making any improvement in any of the areas of the company. The Kaizen methodology is a system for communicating ideas throughout the company hierarchy, encouraging everyone to seek and exploit new opportunities and dismantling barriers to information flow. Kaizen looks at quality within the framework of an organization's existing processes, seeking to enhance these processes to achieve incremental improvement. The Kaizen process does not focus on massive reorganization change (Skrzypek, 2012). The lean management concept involves a change in the organizational structure. It is about "lean organization" by reducing management levels (flattening the organizational structure). Management functions are partially taken over by teams (team management). Employees receive a broader range of responsibilities and powers. The model organization, formed after the process of "weight" started to be network structure. People are the most important factor in the company accordance with Kaizen phylosophy. Company accordance with Kaizen should are about 
employees' needs. In the Table 1 was presented differences between Japanese and Western approach to the quality.

Table 1

Differences between Japanese and Western approach to the quality

\begin{tabular}{|c|c|c|}
\hline Factor & Japanese approach & Western approach \\
\hline Quality & $\begin{array}{l}\text { It is not defined but treated as an } \\
\text { approach. It associates with } \\
\text { everything that can be improved. }\end{array}$ & $\begin{array}{l}\text { Quality is the technical characteristics of } \\
\text { products. Such an understanding is closely } \\
\text { related to technical control. }\end{array}$ \\
\hline $\begin{array}{l}\text { Condition } \\
\text { of work }\end{array}$ & $\begin{array}{l}\text { Based on teamwork and joint } \\
\text { decision-making. }\end{array}$ & $\begin{array}{c}\text { Great importance is placed on the performance } \\
\text { of an individual worker, thereby increasing } \\
\text { competition and competition. }\end{array}$ \\
\hline Promotion & $\begin{array}{l}\text { Companies invest in subordinates, } \\
\text { and although there are no big } \\
\text { payoffs here, and the promotion is } \\
\text { slow, the employee is guaranteed a } \\
\text { lifetime job. }\end{array}$ & $\begin{array}{l}\text { Employees have the option of fast promotion, } \\
\text { which is associated with significant wage } \\
\text { increases, but does not provide stability and } \\
\text { confidence in maintaining a workplace position. }\end{array}$ \\
\hline Control & $\begin{array}{l}\text { Values engagement, ingenuity, } \\
\text { activity and creativity, and the } \\
\text { employee is continually assessed by } \\
\text { management. }\end{array}$ & $\begin{array}{l}\text { A system of penalties and rewards is used, the } \\
\text { employee is constantly monitored, evaluated } \\
\text { according to established standards. }\end{array}$ \\
\hline $\begin{array}{c}\text { Technical } \\
\text { development }\end{array}$ & $\begin{array}{l}\text { In Japan technical progress is a } \\
\text { constant change of all processes } \\
\text { only supported by existing } \\
\text { technologies. Everything here is } \\
\text { oriented towards people rather than } \\
\text { technology. }\end{array}$ & $\begin{array}{c}\text { Companies in the western approach are } \\
\text { oriented towards a technology that develops } \\
\text { continuously and dynamically. Visible effects are } \\
\text { most important. Constantly looking for new } \\
\text { technologies. }\end{array}$ \\
\hline $\begin{array}{l}\text { The most } \\
\text { important } \\
\text { element }\end{array}$ & $\begin{array}{l}\text { Japanese companies take into } \\
\text { account the need for innovation } \\
\text { without forgetting the need to } \\
\text { continually improve existing } \\
\text { standards. }\end{array}$ & $\begin{array}{c}\text { The Western approach is focused on rapid } \\
\text { changes that bring immediate results, focus on } \\
\text { technology and goals - not on people. }\end{array}$ \\
\hline
\end{tabular}

Source: own study

Kaizen events have been widely reported to produce positive change in business results and human resource outcomes (Glover et al., 2011). The Lean initiatives typically have been implemented using the Kaizen Breakthrough Methodology concept, where cross-functional teams are guided by business improvement objectives to reduce overall lead times via the elimination of waste in the process (Ten Step Inc. Supplemental Paper, "The Birth of Lean Sigma," www.tenstep.com, November 2003). Authors (Behensky et al., 2005) realize that Kaizen concept uses the Lean Management approach to eliminate nonproductive processes as well as promotes creating the 'good change'. The team had the autonomy to make changes in the organization and the ability to build relationships with people within the organization-other members of the team they may not associate with during their normal course of business. This relationship-building enhances overall communication within the organization. Kaizen is treated as a continuous search for opportunities to improve all processes (Imai, 1986 ; Berwick, 1989). "Kaizen" is a small improvement that is made by those who do the work (Wolniak, 2013; Wronka, 2013; Skrzypek, 2010). It is a small, low-cost, low-risk improvement that can be easily implemented (Burchart - Korol and Furman, 2009; Nowicka, 2013; Tesler, 2007a; Tesler, 2007b). Kaizen is an ongoing methodology and philosophy for challenging and empowering everyone in the organization to use their creative ideas to improve their 
daily work. The word Kaizen, the way it is typically used, is synonymous with the phrase "continuous improvement." An effective Kaizen approach is about making improvements that are connected to measurable results and a deeper purpose. Authors (Suarez-Barraza and Ramis-Pujol, 2014; Wiśniewska, 2005) noticed that Kaizen helps this public service organization to improve cycle times in the human resource selection and hiring process. Kaizen also accordance with authors (Liker, 2004) focuses on improving the quality of processes in organizations thanks to reducing their cycle time, operating costs, but also by creating continuous flows, satisfying customers and eliminating waste. Term Kaizen, is a Japanese word that basically means "continuous improvement or the principles of continuous improvement" (Lillrank and Kano, 1989). It was coined and disseminated within the field of operational management by Masaaki Imai (1986), in his well-known book Kaizen, The Key to Japan's Competitive Success. Authors (Furterer and Elshennawy, 2005; Rembowski, 2011; Furterer and Elshennawy, 2005) claims that Kaizen can be implemented in service processes in a public context when it concentrates on eliminating "activities that do not add value" (muda). Researchers carried out by (Wittenberg, 2010) showed that Kaizen is able to help to reduce the cycle time of human resource selection and hiring process, maintaining its performance, adopting a standard set by listening to the customer as well as this is an excellent way of improving the performance of service processes, and the corresponding quality of the public services provided to internal and/or external customers. The kaizen strategy is based on the process of gradual change bringing improvements to all area of management and production. It is a people based system with standardization being an essential feature (Dickson et al., 2009). The Kaizen event is a way of learning by doing (Kim, 2006) as well as noticed (Smith, 1990) it is a system of continuous improvement all processes. Kaizen places the emphasis on process rather than outcome, as the most effective means of improving a service. Fear must be a bolished (Witkiewicz et al. 2012). The essential features kaizen can indicate (Ito et al., 1998; Nembhard and Edmondson, 2006):

- basing on existing technologies,

- human orientation, problems, processes, customer,

- perform all processes with sincere dedication,

- attaching importance to the process details,

- teamwork,

- strong feedback,

- long-term effects.

\section{PAPER STRUCTURE FASHION FOR RUNNING IN POLAND IN QUALITY OF LIFE IMPROVEMENT}

Quality of life is a result of the individual's attitude towards its own psychological and physical well-being, material existence, interpersonal relations possessed, possibilities of personal development and a sense of subjectivity (Walczak and Tomczak, 2011; Tetsuya et al., 2006 ; Padilla et al., 1983; Stempień, 2018). According to the World Health Organization, the individual's quality of life should be understood in the context of her perception its life situation, related to the cultural context and the system of values accepted by the society in which the individual lives, and in relation to life goals, expectations and interests. Running fashion is a 
phenomenon observed not only on the Polish or European scale, but also on the world scale. In recent years in Poland there is a growing interest in running and a healthy, active lifestyle. Recreational sport is an organized way of spending free time, thanks to which you can both develop health potential by engaging in a planned, controlled training process, as well as significantly improve the quality of life by participating in sports and recreational events. Running is nowadays the third most popular discipline of motor recreation in Poland, giving way only to cycling and swimming. Running as a form of active rest has never been so popular in Poland as it is now. Research carried out by the authors Stempien and Waśkowski, show that the reasons for taking up running activity concern such aspects as: the desire to improve the form, weight loss, fight with the addiction, the pleasure felt, the willingness to check, the need for competition (Nowak, 2012; Wolańska, 1997). Author Nowak P. F. (Nowak, 2012) show that for most runners, health is the main declared motive of running. Many people start running to, for example, reduce weight or improve overall health. After achieving the original goals, as the physical fitness develops, there are more, related to self-improvement. Running health training, as a process directed especially at the development of the body's efficiency may, in its most developed form, be associated with participation in sporting and recreational events, during which rivalry takes place. You can compete with yourself, distance, with time, difficult route profile or weather. Most runners have their own goals and set their own categories of rivalry, for example, rivalry may apply to the number of runs crossed in a year. It is worth noting that independently set goals can also be irrational and completely unrelated to a healthy or healthy lifestyle. The highest growth rate in the number of runners can be observed in the last few years. According to various estimates, there are currently running between 1 and 3 million Poles in our country, the exact number cannot be determined due to the mass character of this phenomenon, and above all due to the differently adopted definition of a runner (Omyła-Rudzka, 2013; Dziubiński, 2013; Stempień, 2013 ; Waśkowski, 2014). This sport is much more common for men, women in the Polish runners' environment constitute about $20-30 \%$. Research carried out by author Waśkowski shows that the most important determinants favoring the popularity of running Poles include a healthy, active lifestyle, high popularity of running in Western countries, and the increasing availability of high-quality footwear, clothing and accessories for runners, increasing number of mass running events, running fashion, relatively low cost of practicing this sport and, above all, no special requirements for sports arenas. The same author in other studies showed that women are more likely to compete in races, the proceeds of which are intended for charity purposes, they also willingly participate in social purposes, while much less often with a focus on competition with others (Nowak and Supiński, 2014; Waśkowski, 2007).

\section{QUALITY OF LIFE IMPROVEMENT BY SMALL STEPS IN RUNNING ASPECT IN POLAND - METHODOLOGY AND RESULTS}

The aim of the research is to analyze the quality of life improvement (Kaizen) in the running aspect in Poland. Until now, issues related to the running analysis of the quality life in terms were not the subject of broader, comprehensive scientific considerations. The research was taken in 2019 year and covered a group of 396 runners. The respondents are women posing $67,9 \%$ and men posing $32,1 \%$ residing in different areas of Poland. Based on literature research and the analysis of the 
activities of selected enterprises, the following hypothesis was formulated: using the well-known factors determining physical activity, the impact of running on runners' quality. The research was based on a questionnaire (CAWI - Computer Assisted Web Interview). The analysis of data regarding the reasons for taking up physical activity (Figure 1) shows that respondents, mainly thanks to running, feel happy through secreted endorphins (59.7\%). Studies also show that running is a therapy in the fight against stress (53.1\%). Respondents clearly indicated (fig. 2) in the research that running gives them the opportunity to test their abilities $(61.2 \%)$. In the next stage of the research, the runners were asked what they think about while running. It turns out that running activity allows respondents to completely turn off, even escape from problems (60.8\%). 33.3\% of runners felt that physical exercise, which is running, allows them to find a solution to problems. In the research, the respondents were asked whether running increased their quality of life and as much as $97.2 \%$ of respondents noticed a lot of benefits from taking up running activity. Not only in terms of quality of life, but also in the field of improving running results in small steps, that is Kaizen.

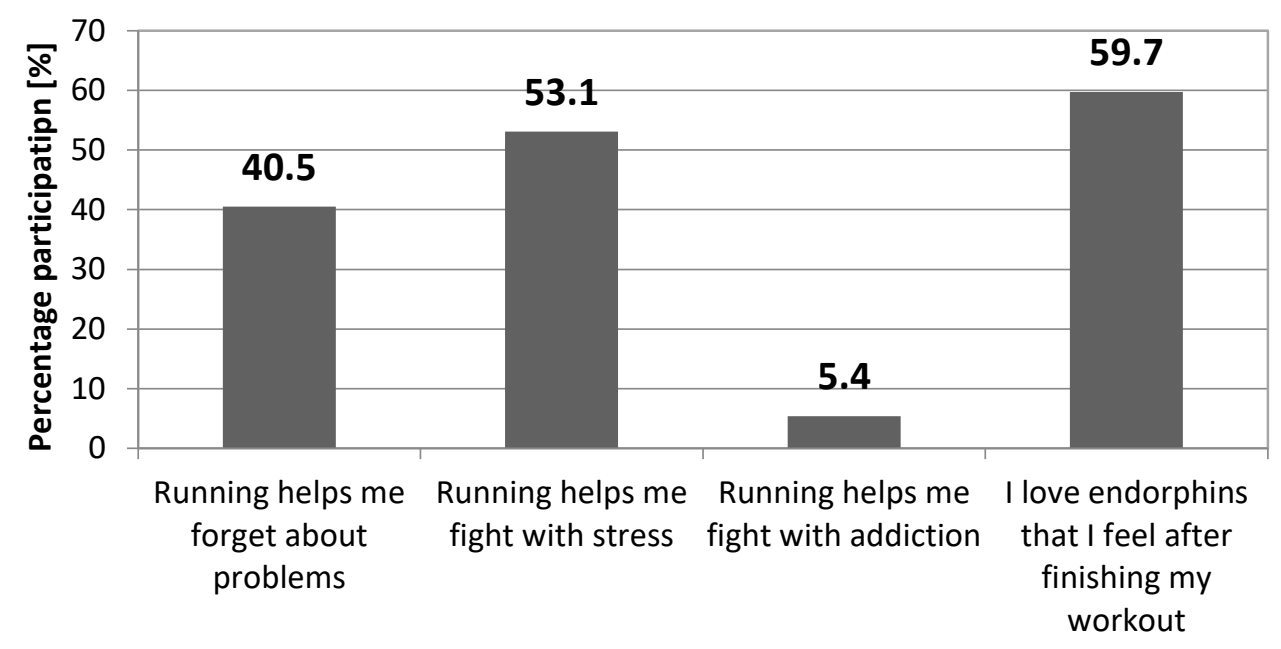

Name of factor

Fig. 1. Why are you running?

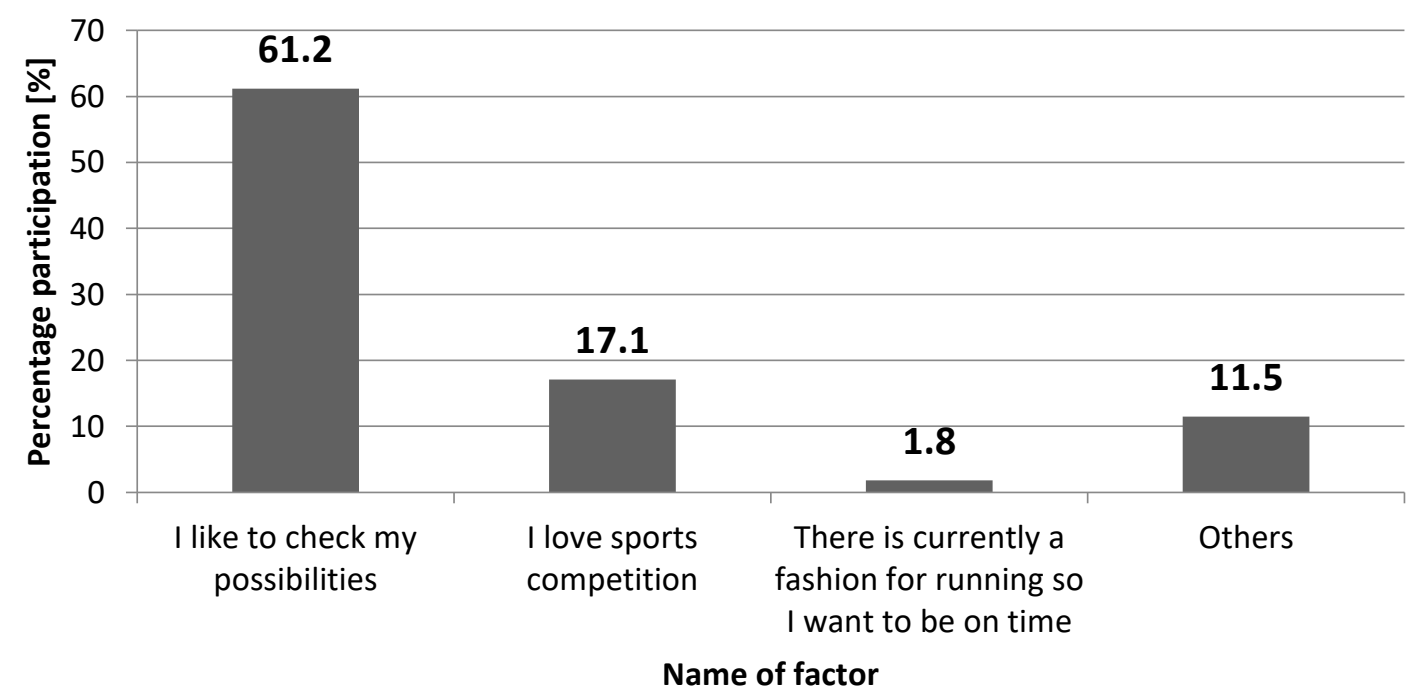

Fig. 2. Why do you undertake running activity? 


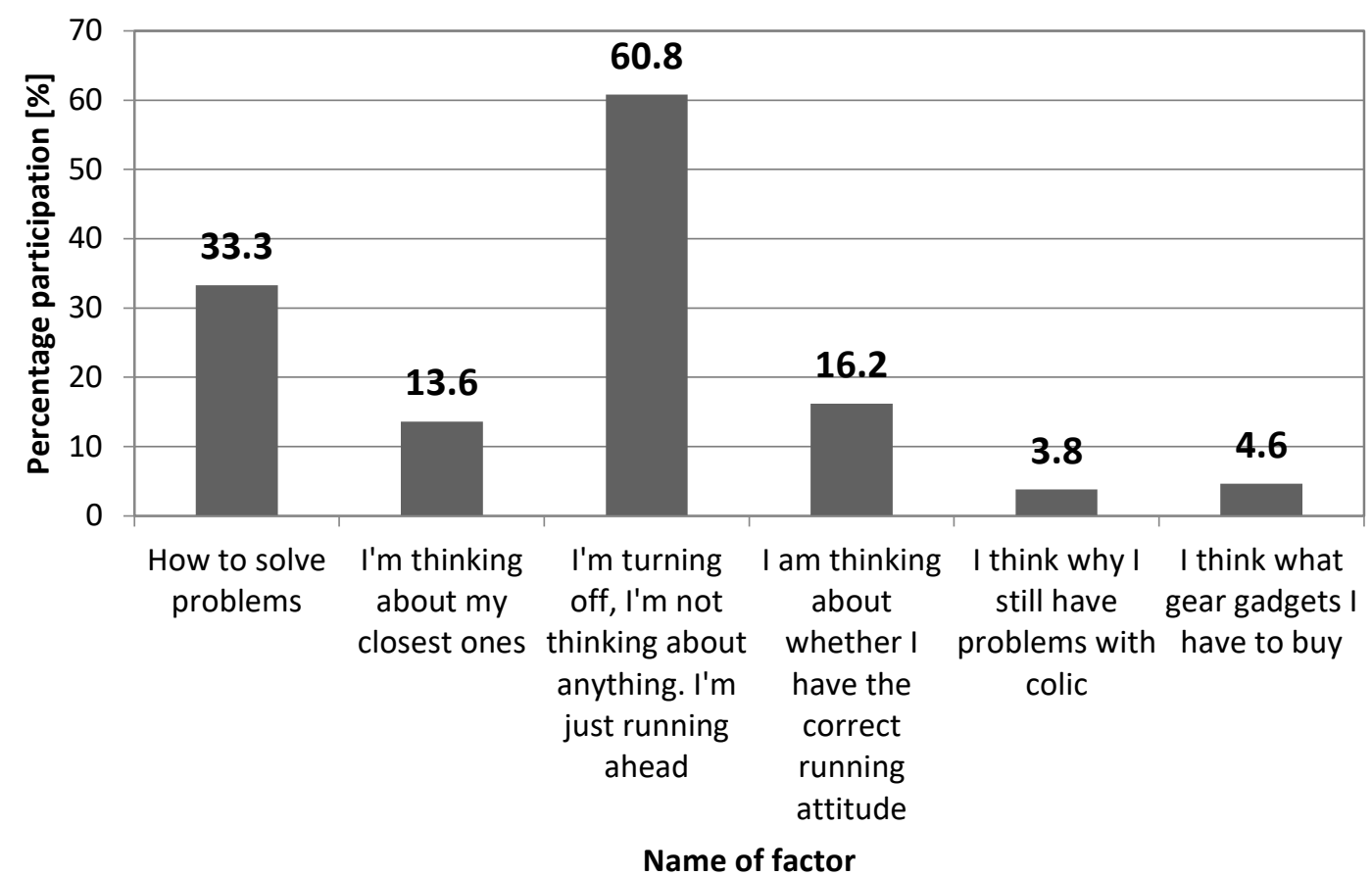

Fig. 3. What are you thinking about during running activity?

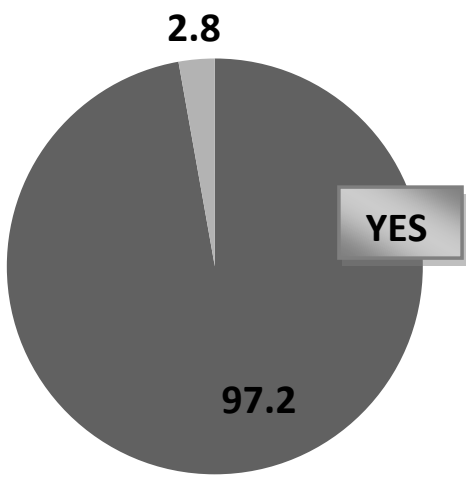

Fig. 4. Do you think that running increases the quality of life?

\section{CONCLUSION}

The article presents the issue quality of life improvement in Kaizen aspect. People start running for a variety of reasons. Somerun because they want to lose weight, improve their health, compete in races or try something new. Whatever your reason is for running, you'll experience many physical, mental and emotional benefits of the sport. Running is an excellent way to strengthen the heart and ensure the efficient flow of blood and oxygen throughout the body, which helps decrease your risk of a heart attack. Exercise, combined with maintaining a healthy weight, is one of the best ways to naturally reduce your blood pressure if it's above normal. Running also improves your immune system, so your body functions are more effective and efficient at fighting off germs. Running can also be used as a way to contribute to society as a whole. Many races benefit charities, and some charities offer race 
training in exchange for fund-raising. The sport gives people the opportunity to explore areas of their own community or new locations, experience new physical sensations and run places they may not normally see. Runners who run in the morning report that they have improved energy levels during the day. Indeed, a 2012 study in the Journal of Adolescent Health proved that just 30 minutes of running during the week for three weeks boosted sleep quality, mood, and concentration during the day. The research was taken in 2019 year and covered a group of 396 runners. The respondents are residing in different areas of Poland. Research has shown that running is treated as a way to be fashionable, but in most cases as a way to deal with stress. Most of the runners surveyed decided to run because it's a way for them to forget about problems, it is easier to fight stress thanks to running, they love endorphins that are released after the training. Respondents show very many reasons why they decided to run:

- they decided to test their abilities,

- many runners love sports competition, which they did not find in the gym,

- a way to lose weight,

- a way to personal problems,

- a way to fight the addiction.

Although for most respondents the result is not the most important, they try to improve their running attitude and time. Runners use different ways to be motivated to work on themselves. An example of motivators can be a medal, obtained at the finish line or sharing success with participation in competition on social networks (Facebook).

\section{References}

Behensky, J. A., Janet Roe, M. S. \& Bolton, R. Lean Sigma - Will it work for Healthcare? FOCUS: Organizational Improvement/Project Management. Journal of Healthcare Information Management, 19 (1): 39-44, (2005).

Berwick, D.M. Continuous improvement as an ideal in health care. New England Journal Medicine, (320): 53-56, (1989).

Burchart - Korol D., Furman J. Kaizen jako strategia zwiększania konkurencyjności przedsiębiorstw hutniczych, Hutnik, Nr 2, s. 158-162, (2009).

Dickson E.D., Zlatko A., Vetterick D., Eller A., Singh S. Use of Lean in the Emergency Department: A Case Series of 4 Hospitals, Annals of Emergency Medicine, Volume 9, October: 504-510, (2009).

Dziubiński Z. Zmiana społeczno-kulturowa a renesans sportu powszechnego $w$ Polsce, [w:] A. Kaźmierczak, J. E. Kowalska, A. Maszorek-Szymala, A. Makarczuk (red.), Pedagogiczny wymiar kultury fizycznej i zdrowotnej w życiu współczesnego człowieka, Wydawnictwo Uniwersytetu Łódzkiego, Łódź, (2016)

Furterer, S., Elshennawy, A. Implementation of TQM and Lean Six Sigma tools in local government: a framework and a case study, Total Quality Management, Vol. 16, No. 10: 1179-91. (2005).

Glover W.J., Farris J.A., Van Aken E.M., Doolen T.N. Human resource outcomes: An empirical study, International Journal of Production Economics, Volume 132, Issue 2, August: 197-213 (2011).

Imai K. KAIZEN. New York: Random House, (1986).

Ito H., Iwasaki S., Nakano Y., Imanaka Y., Kawakita H., Gunji A. Direction of quality improvement activities of health care organizations in Japan, International Journal for Quality in Health Care, Volume 10, Number 4: 361-363, (1998). 
Kim CS, Spahlinger DA, Kin JM. Lean health care: what can hospitals learn from a world-class automaker? Journal Hospital Medicine, No. 1: 191-199, (2006).

Liker, J. The Toyota Way, Simon \& Schuster, New York, NY, (2004).

Lillrank, P. And Kano, N. Continuous Improvement-Quality Control Circles in Japanese Industry, University of Michigan, Ann Arbor, MI, (1989).

Manuel F. Suárez-Barraza, Juan Ramis-Pujol, Su Mi Dahlgaard-Park, Changing quality of life through the Personal Kaizen approach: a qualitative study, International Journal of Quality and Service Sciences, Vol. 5 Issue: 2, pp.191-207, https://doi.org/10.1108/IJQSS-03-2013-0015, (2013).

Nembhard I. M., Edmondson A. C. Making it safe: The effects of leader inclusiveness and professional status on psychological safety and improvement efforts in health care teams, Journal of Organizational Behaviour, No 27: 941-966 (2006) Published online in Wiley interscience, (2006).

Nowak P. F., Supiński J. Uczestnictwo w biegach maratońskichA zdrowotność polskich biegaczy. Rozprawy naukoweAkademii Wychowania Fizycznego We Wrocławiu 45, s. 41-47, (2014).

Nowak P.F. Poziom zaangażowania polskich biegaczy w ich sportową pasję, [w:] Siwiński W., Pluta B. (red.), Teoria i metodyka rekreacji ruchowej w świetle aktualnych badań, Bogucki Wyd. Naukowe, AWF, Poznań, 290-301. Wyd. Naukowe, AWF, Poznań, 290-301, (2012).

Nowicka I. Rola menadżerów przy wspieraniu procesów Kaizen, Kaizen, Nr 11, 20-24, (2013).

Omyła-Rudzka M. Aktywność fizyczna Polaków, komunikat CBOS, nr 4887, (2013).

Padilla G.V., Presant C., Grant M., Metter G., Lipsett J., Heide F. Quality of Life Index for Patients with Cancer, Research in nursing and health, Volume 6, Issue 3, pp. 99-154, (1983).

Rembowski Ł. Wyścig z czasem. Top Logistyk, Nr 6-7: 48-51, (2011).

Skrzypek A. Kaizen jako narzędzie doskonalenia zarządzania w przedsiębiorstwie, Problemy Jakości, Nr 2 (2012).

Skrzypek E. Kaizen. Problemy Jakości. Nr 7, 18-21, (2010).

Smith, R. Medicine's needs for Kaizen: putting quality first. Editorial, British Medical Journal, 301: 679-680, (1990).

Stempień J. R. Ku Źródłom Polskiej Mody Na Bieganie - Perspektywa Nietzscheańska, Acta UniversitatisLodziensis Folia Sociologica 58, ' (2016).

Stempień J. R. Moda Na Bieganie - Doświadczenia Polski I Innych Krajów Analiza Porównawcza, Acta Universitatis Lodziensis Folia Sociologica 65, (2018), s. 89107.

Suarez-Barraza M. F., Ramis-Pujol J. (2010). Implementation of Lean-Kaizen in the human resource service process. A case study in a Mexican public service organisation, Journal of Manufacturing Technology Management, Vol. 21, No. 3: 388-410.

Suarez-Barraza M. F., Ramis-Pujol J. Implementation of Lean-Kaizen in the human resource service process. A case study in a Mexican public service organisation, Journal of Manufacturing Technology Management, Vol. 21 No. 3: 388-410, (2010).

Tesler D. Kompetencje menedżera Kaizen, cz.1, Logistyka a jakość, Nr 3, 40-43, (2007a).

Tesler D. Kompetencje menedżera Kaizen, cz.2, Logistyka a jakość, Nr 4: 40-43, (2007b). 
Tetsuya O., Schmitz K.Z., Ahmed R.L., Yee D. Effects of Weight Training on Quality of Life in Recent Breast Cancer Survivors, Cancer, Volume106, Issue 9, pp. 20762083, (2006).

Walczak M., Tomczak M. Poczucie jakości życia jako efekt zaspokojenia potrzeb psychologicznych i zróżnicowania motywacji do aktywności fizycznej, Zeszyty Naukowe Uniwersytetu Szczecińskiego, Ekonomiczne Problemy Usług Nr 78, (2011).

Waśkowski Z. Profil polskiego biegacza. Raport z badań, (2014).

Waśkowski Z., Uwarunkowania $i$ sposoby wdrażania orientacji marketingowej w klubach sportowych, Wyd. Akademii Ekonomicznej w Poznaniu, (2007).

Wiśniewska M. Osiągnięcie efektywnych procesów i całej organizacji jest możliwe. Czy Kaizen pozwala osiągnąć ten cel? Problemy Jakości, Nr 1: 24-27, (2005).

Witkiewicz W., Cymbała V., Fiałkowska M. Możliwość wykorzystania prostych narzędzi poprawy jakości opartych na filozofii kaizen przy wdrożeniu Okołooperacyjnej Karty Kontrolnej, XVI Ogólnopolska Konferencja Jakość w Opiece Zdrowotnej, Centrum Monitorowania Jakości w Ochronie Zdrowia: 67-75, (2012).

Wittenberg G. (2010). Kaizen — The many ways of getting better, MCB UP Ltd. ISSN: 0144-5154.

Wolańska T. Leksykon. Sport dla wszystkich - rekreacja ruchowa, AWF, Warszawa, (1997).

Wolniak R. Wykorzystanie Kaizen w przedsiębiorstwie produkcyjnym, Problemy Jakości, Nr 6: 12-20, (2013).

Wronka A. Ryzyko w procesie realizacji usprawnień KAIZEN, Problemy Jakości, Nr 10, s. 23-28, (2013). 